\title{
千里ニュータウンにおける居住世带の家計構造 と購買施設利用形態に関する研究 (その1)
}

\author{
正会員広原 盛 明* 正会員梶浦 恒 男**

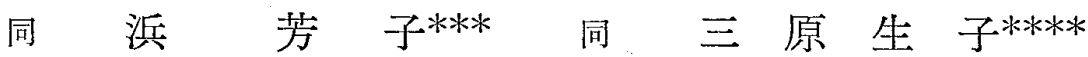

\section{1. 研究の意義と目的}

従来大都市近郊に立地する住宅地計画に晾いて，居住 者の近隣消費および購買施設経営の両側面からいくつか の標淮店舗構成や規模に関する研究が行なわれてきた。 当初これらの研究は，食料品，日用品などの最寄品店舗 の計画資料として，人口約 1 万人・約 2 千世帯の近隣住 :区規模の住宅地に適用されるものと考光られていたが， 住宅地開発が次第に大型化するにつれ，最寄品を主とす る近隣第 1 次消費に加えて，買廹り品，專門品などの近 燐第 2 次消費, さらに娛楽性消費を含めた都心性消費な ぞに関する研究が媣められ，その成果は大団地やニュー タウンなどで近隣店舗から中央店舗に至る一連の購買施 設構成として適用されつつある。

しかしながら，主婦の日常生活にとって最む関連の樑 いこの購買施設が，数ある地域施設の中で最も不満の集 中する施設であるという注目すべき事実がある。それら 壮主として 1 業種 1 店舗からなる近隣購買施設の経営に 対する不満一一品物が少ない，古い，值段が高い，接客 㮩度が悪い，閉店時間が早い，等々—となってあらわ れ，自治会と店主側との団体交涉，不買運動，青空市場 の誘置，生活協同組合の設立など，具体的な住民運動に まで発展することが多い。

もともと 1 業種 1 店舗というかたちの近隣購買施設は 覞存市街地に打ける購買施設構成の規模とこれの経営を 可能とする人口数との対态関係，および購買施設の生態 的誘致圈の調查分析から導きだされてきたものである。 しかし現実の市街地では，1業種1店舗といったかたち の購買施設はきわめて稀で同業複数)店舗の競存が一般的 である。そこでは，める一定の範围内で居住者が自由に 選択できる複数の店舗配置と，サービスしなけ机ば客を 他の占にとられるといら経営方針一一自由競走の原則 一が效忘していた。

近隣住区理諭の一環として適用された 1 業種 1 占舗の 近隣購買施設構成は，もともと複数店舗とこれにみあう 人口数といらかたちではじめて空間的, 経営的両側面か らバランスのとれていた購買施設の利用形態から，「店

* 京大助手 $* *$ 大阪市大助手 $* * *$ 奈女大院生 $* * * *$ 京大 技官

（昭和 42 年 10 月 22 日本稿受理・討諭期限昭和 43 年 8 月末日)
に近い」という空間的要因を重視し，従ってサービス圈 をできるだけ短くするために 1 業種 1 店舗とい5「純 粋」なかたちを抽出した結果，「品物が良い」「值段が安 い」などの経営的要因を捨象することとなってしまった のである。いいかえれば， 3 店舗 3 万人の対态関係と 1 店舗 1 万人とのそれとは，全く質的に異なることが見落 されていたといえる。

しかも最近に至っては，この購買施設をめぐって施設 経営と利用者の両側面汃ら，いくつかの構造的変化があ らわれ始めていることも見逃せない。そのひとつはスー パー・マーケットの進出やチェーン・ストアの形成とい った購買施設形態自体の変化であり，他のひとつは主婦 の社会労働への進出による共働き世带の増加，およびそ れにさもなら購買慣習の変化である。「計画」されている がゆえに，この様なダイナミックな変化に対応し得ない 1 業種 1 店舗の近隣購買施設は，今やその矛盾をますま

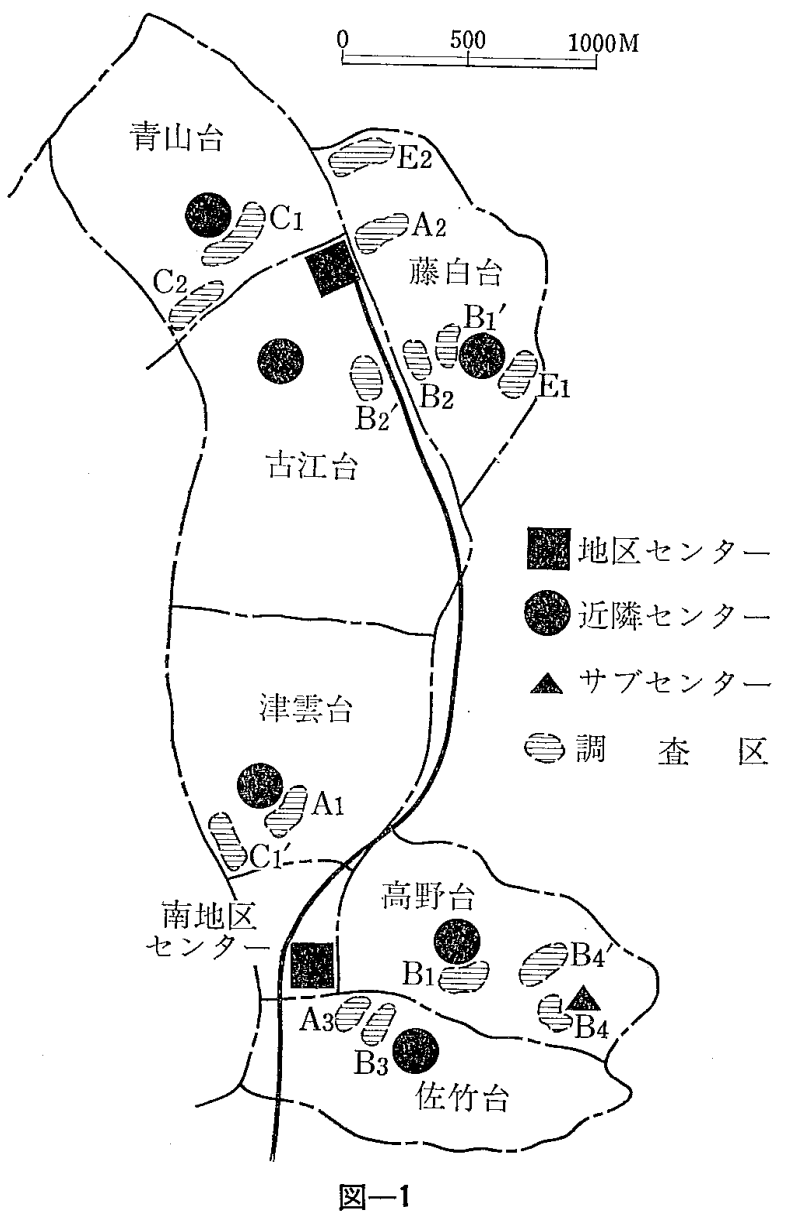


す深めることによって大きく再検討を迫られようとして いるし，それはまた，購買施設が大きな比重を占める近 隣住区理諭の再検討にもつらなるものであるら。

本研究は以上の様な問題設定の上に立って, 購買施設 における空閒的要因一一購買施設の性格, 規模, 立地, 居住者加らの距離等一一, 社会・経済的(経営的)要因 一一購買施設の経営状態，居住者の収入，家族形態，主 婦の労働形態等—とが，居住者の購買施設の利用形態 の上にどの椂な関連をもってあらわれてくるかの追求に 研究の焦点をしぼった。いわば購買施設の適正規模やそ の配置計画に直接に役立つ研究というよりも，むしろ従 来との椂な手法ですすめられてきた研究が，実際に適用 された段階でひき起している数々の矛盾を明らかにする ことが研究の重点である。従ってこの場合，いろんな条 件を異にする調查対象の選定がきわめて重要であり，ま た購買施設の利用形態の調查も，これらの条件がごの様 なかたちで岁われてくるかをチェックできる程度の精 度をもつものでなければならない。

以上の点から, 購買施設の利用調查で従来行なわれて きたアンケート式の商品購買地点調查は不適当であると 考えられる。なぜなら，「次の品物を買うのはどこか」 といった質問に刘してアンケート式にその地点を記入す るなら，ある地点でその品物の $90 \%$ を買っている場合 と 60\% 買っている場合の相異はみわけられないし，ま た主要な地点と補助的な地点を記入するとしても，それ がぞれぐらいの比率で分かれているのかは不明である。 このため購買施設や居住者の条件が利用形態にどの様な
影響を及ぼしているかを正確にとらえるためには，客観 的な金額がつかめる家計調查（購買地点別）が最も適当 と思われる。

\section{2. 調查方法}

1966 年 11 月 1 日 30日の 1 力月間，千里ニュータウ ン居住世带を対象として支出品目と金額および購買施設 の記入できる家計簿起配布し，家計調查を実施した。調 查対象世帯は，千里ニュータウン内の各種䝼買施設（南 地区センター，各住区近隣センター，高野台サブセンタ 一）に対する居住世带の位置関係と，居住世帯の住宅階 層(公営, 公団, 公社, 分譲の各住宅)を組み合わせて, 1 調查区約 25 世帯, 計 15 調查区 350 世帯の有意抽出に よった。350 世帯のうち調查拒否 103 世炗, 家計簿の配 布は 247 世帯, 最終集計が可能となったのは 227 世带で 配布数の $82 \%$ であった。

\section{3. 調查世帯の概要}

調査世带の性格については, 家族形態, 職業, 収入, 学歴などの基本的属性加考えて, 公営住宅, 公団・公 社住宅，分譲住宅の居住世帯間に比較的明らかな差がタ られるので，以下各住宅階層ごとにその概要を記すにと どめる(表-3.1)。

公営住宅居住世帯（以下〈公営〉といら）は，世帯主 の職業が事務・技術職員を中心にして，販売少ービス從 事者, 熟練労働者が多く，学歴は大学卆も多いが主体は 高校卆である。第 1 子が就学前あるいは小学生の若い夫 婦家族が中心で，人数は 3,4 人が多い。収入は 4,5 万 円台が最も多く，主婦の $1 / 4$ が内職をしている。

表一3.1 千里ニニータウン居住世带における住宅階層別, 家族形態, 職業形態, 収入状況

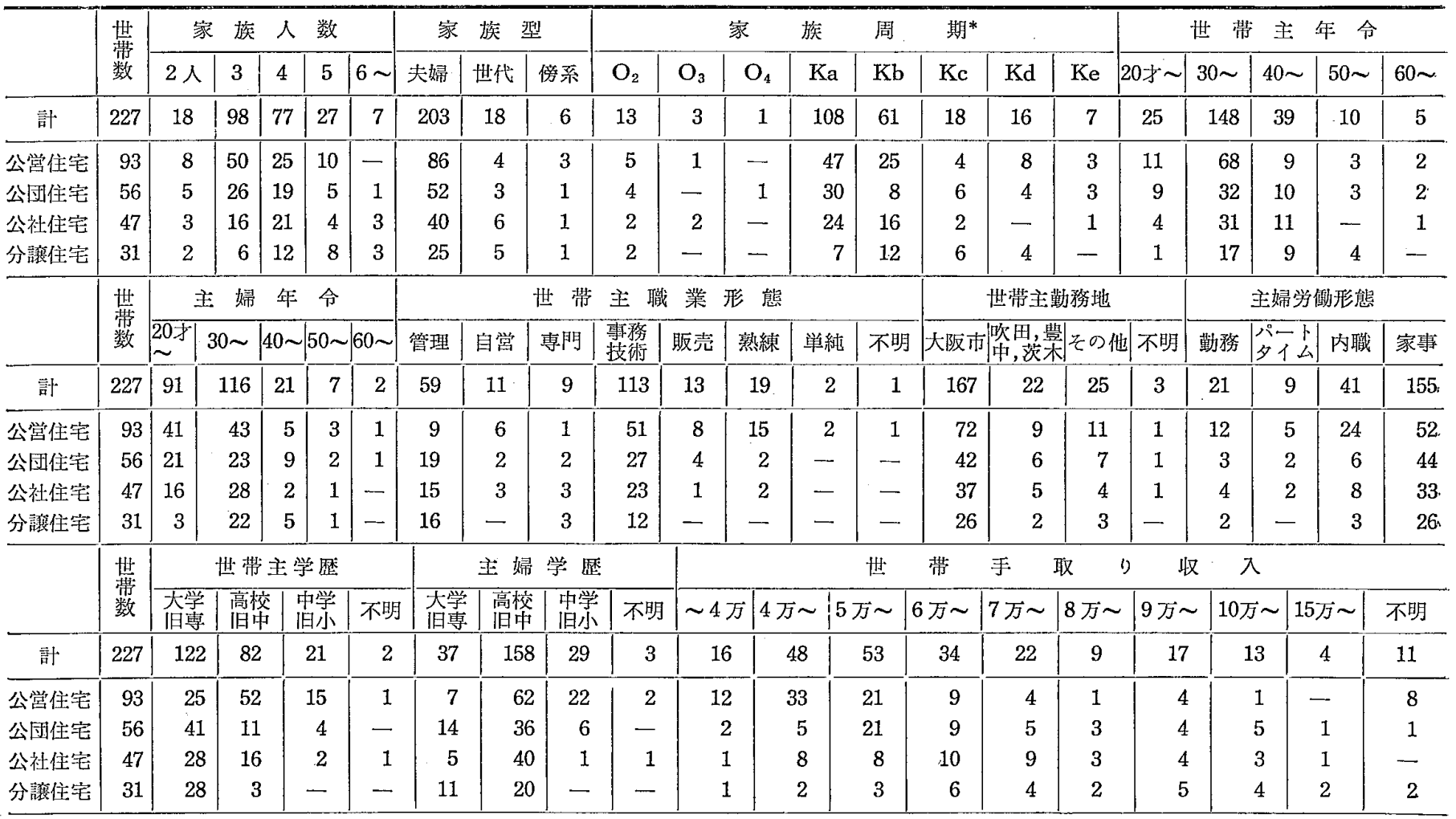

* 家族周期 $\mathrm{O}$ 子供無 婦令 20 才代 $\mathrm{O}_{2}$ 婦令 30 才代 $\mathrm{O}_{3}$ 婦令 40 才代 $\mathrm{O}_{4}$

○子供有 第1子 $0 \sim 5$ 才 $\mathrm{Ka}$ 第 1 子 6 11才 $\mathrm{Kb}$ 第 1 子 12 17才 Kc 第1子 18〜24才 Kd 第 1 子 25 才 $\mathrm{Ke}$ 
公団・公社住宅居住世帯(以下<公 団公社〉という）は，世帯主職業が 事務・技術職員と専門・管理職でそ のほとんどを占め，大学卆中心の木 ワイトカラーである。家族は第1子 が就学前の若い夫婦家族が多く，人 数は 3,4 人が多い。収大は $5 \sim 7$ 万 円台に一応の中核はあるもののその 分散度が大きく，世帯主の年令の差 による収入の差が影響しているもの と思われる。

分譲住宅居住世帯(以下〈分譲〉と (ら)は,世帯主の職業が専門・管理 職と事務・技術職員でそのほとんど を占める。学歴は大学杂が主体であ る。家族は，第 1 子が就学前のものか ら中・高校在学中のものまでに分散

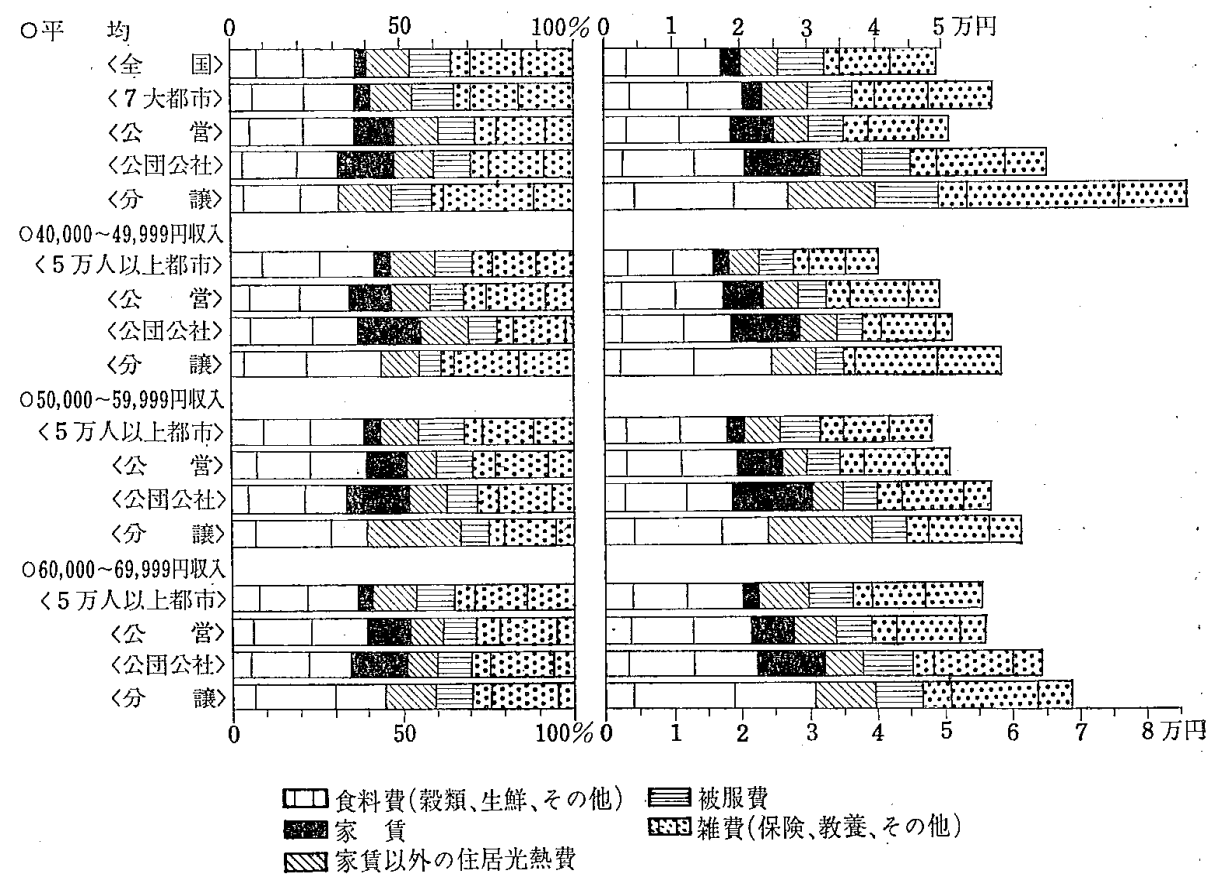

図-4.1

しており，従って人数も 3 人から 5 人あたりまでひろがはあるが,全体としては 6 万円より上位に集中している。 っている。収入は世带主の年令によって比較的バラッキ４．家 計 構 造

表一4.1 千里ニュータウン居住世帯の住宅階層別家計構造および全国七大都市比較

\begin{tabular}{|c|c|c|c|c|c|c|c|c|c|c|}
\hline & $\begin{array}{l}\text { S.41.11 } \\
\text { 全国勤学 } \\
\text { 者世常 } \\
\text { (実数) }\end{array}$ & 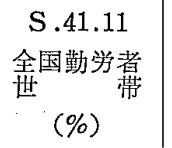 & 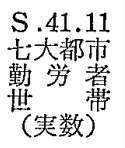 & $\begin{array}{c}\text { S.41.11 } \\
\text { 七大都市 } \\
\text { 勵営者世带 } \\
(\%)\end{array}$ & $\begin{array}{c}\mathrm{S} .41 .11 \\
\text { 調查〈公営〉 } \\
\text { (实数) }\end{array}$ & $\begin{array}{c}\mathrm{S} .41 .11 \\
\text { 調查〈公営〉 } \\
(\%)\end{array}$ & $\begin{array}{c}\text { S.41.11 } \\
\text { 調查〈公団 } \\
\text { 公社〉 } \\
\text { (実数) }\end{array}$ & $\begin{array}{c}\text { S. } 41.11 \text { 調查 } \\
\text { 〈公団公社〉 } \\
(\%)\end{array}$ & $\begin{array}{c}\mathrm{S} .41 .11 \\
\text { 調查〈分㒛〉 } \\
\text { (実数) }\end{array}$ & $\begin{array}{c}\text { S.41.11調查 } \\
\cdots \text { 〈分譲〉 } \\
(\%)\end{array}$ \\
\hline 収 入 総 額 & 71,276 & 100.0 & 79,641 & 100.0 & 64.700 & 100.0 & 82,538 & 100.0 & 102,003 & 100.0 \\
\hline 収 & 59,663 & $83.7(100.0)$ & 68,600 & $86.2(100.0)$ & 59,553 & $92.0(100.0)$ & 78,840 & $95.6(100.0)$ & 97,461 & $95.6(100.0)$ \\
\hline 勤 先 収入 & 55,505 & $78.8(93.0)$ & 63,782 & $80.1(93.0)$ & 53,554 & $82.8(90.0)$ & 75,254 & $91.2(95.4)$ & 92,347 & $90.5(94.7)$ \\
\hline 世蒾主 収 入 & 49,242 & $69.1 \quad(82.5)$ & 57,795 & $72.6(84.3)$ & 51,644 & $80.0(86.6)$ & 72,812 & $88.2(92.3)$ & 92,347 & $90.5(94.7)$ \\
\hline 妻收不 & 2,444 & $3.4(4.1)$ & 1,172 & $1.5(1.7)$ & 1,806 & $2.8(3.0)$ & 1,838 & $2.2(2.3)$ & - & - \\
\hline その他の世带員収 & 3,819 & $5.4(6.5)$ & 4,815 & $6.0(7.0)$ & 104 & $0.2(0.4)$ & 604 & $0.7(0.8)$ & - & - \\
\hline 事業・内職収入 & 1,907 & $2.7(3.2)$ & 2,237 & $2.8(3.3)$ & 3,878 & $5.9(6.5)$ & 2,372 & $2.9(3.0)$ & 2,875 & $2.8(2.9)$ \\
\hline その他の実収入 & 2,251 & $3.2(3.8)$ & 2,581 & $3.2(3.8)$ & 2,120 & $3.3(3.6)$ & 1,214 & $1.5(1.7)$ & 2,239 & $2.2(2.3)$ \\
\hline 実収入以外の収入 & 11,613 & 16.3 & 11,041 & 13.9 & 5,147 & 8.0 & 3,697 & 4.5 & 4,542 & 4.6 \\
\hline 出 & 70,407 & 100.0 & 78,475 & 100.0 & 60,916 & 100.0 & 82,675 & 100.0 & 122,378 & 100.0 \\
\hline 実 支 & 55,348 & $\begin{array}{ll}78.7 \\
\end{array}$ & 63,112 & 80.4 & 56,721 & 93.2 & 75,273 & 91.0 & 112,472 & 91.0 \\
\hline 消 費 支 & 49,987 & $71.0(100.0)$ & 56,620 & $72.1(100 \cdot 0)$ & 50,396 & $82.8(100.0)$ & 65,238 & $78.9(100.0)$ & 85,873 & $69.4(100.0)$ \\
\hline 料 & 18,171 & $25.8(36.4)$ & 20,554 & $26.2(36.2)$ & 18,658 & $30.6(37.0)$ & 20,936 & $25.3(32.1)$ & 27,573 & $22.3(32.1)$ \\
\hline 款 & 3,948 & $5.6(7.9)$ & 3,928 & $25.0(6.9)$ & 3,161 & $5.2(6.3)$ & 2,924 & $3.5(4.5)$ & 3,821 & $3.1(4.4)$ \\
\hline 生 鮮 食 料 費 & 7,022 & $10.0(14.1)$ & 8,355 & $10.6(14.7)$ & 7,945 & $13.1(15.8)$ & 10,148 & $13 \cdot 3$ (15.6) & 14,432 & $11.7(16.8)$ \\
\hline その他の食料費 & 7,199 & $10.2(14.4)$ & 8,271 & $10.5(14.5)$ & 7,552 & $13.4(15.0)$ & 7,864 & $9.5(12.1)$ & 9,319 & $7.5(10.9)$ \\
\hline 住 居 光 蓺 費 & 7,906 & $11.2(15.8)$ & 9,304 & $11.9(16.4)$ & 12,086 & $19.9(24.0)$ & 17,544 & $21.2(26.9)$ & 12,826 & $10.8(14.9)$ \\
\hline 被＼cjkstart服 & 6,130 & $8.7(12.3)$ & 6,655 & $8.5(11.7)$ & 4,925 & $8.1(9.8)$ & 6,820 & $8.3(10.5)$ & 9,458 & $7.7(11.0)$ \\
\hline 雑費 & 17,780 & $25.2(35.6)$ & 20,107 & $25.6(35.3)$ & 14,728 & $24.2(29.2)$ & 19,938 & $24.1(30.6)$ & 36,017 & $29.1(41.9)$ \\
\hline 保 険 衛生費 & 2,660 & $3.8(5.3)$ & 3,018 & $3.8(5.3)$ & 3,009 & $4.9(6.0)$ & 3,408 & $4.1(5.2)$ & 3,188 & $2.6(3.7)$ \\
\hline 教養文化費 & 7,583 & $10.8(15.2)$ & 8,089 & $10.3(14.2)$ & 7,734 & $12.7(15.4)$ & 10,802 & $13.1(16.6)$ & 22,562 & $18.2(26.3)$ \\
\hline その他の雑費 & 7,537 & $10.7(15.1)$ & 9,000 & $11.5(15.8)$ & 3,981 & $6.5(7.9)$ & 5,727 & $6.9(8.8)$ & 10,267 & $8.3(11.9)$ \\
\hline 非 消 費 支 出 & 5,361 & 7.6 & 6,492 & 8.3 & 6,325 & 10.4 & 10,035 & 12.1 & 26,599 & 21.5 \\
\hline 税金 & 2,501 & 3.6 & 3,600 & 4.6 & 2,444 & 4.0 & 5,725 & 6.9 & 22,159 & 17.9 \\
\hline 社 会 保 障 費 & 2,860 & 4.0 & 2,892 & 3.7 & 3,881 & 6.4 & 4,310 & 5.2 & 4,440 & 3.6 \\
\hline 実支出以外の支出 & 15,059 & 21.4 & 15,363 & 19.6 & 4,195 & 6.9 & 7,402 & 9.0 & 9,906 & 8.0 \\
\hline 貯 金 & 6,607 & 9.4 & 7,808 & 9.9 & 2,472 & 4.1 & 5,070 & 6.1 & 2,370 & 1.9 \\
\hline 他 & 8,452 & 12.0 & 7,555 & 9.6 & 1,723 & 2.8 & 2,332 & 2.9 & 7,536 & 6.1 \\
\hline
\end{tabular}

註） ○収入および支出総額には，繰入金，繰越金は含まれていない。

$\bigcirc$ 総理府家計調查統計における消費支出の品目を以下の要領で簡略化した。そのままの品目は省略する。( )内は総理府品名。 生鮮 食料 費 (生鮮魚介類, 肉類, 乳卵類, 野菜類, 果物類)

气の他の食料費 (乾物海草類, 加工食品, 調味料, 菒子類, 酒類, 领料, 外食費)

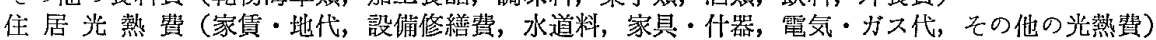

保 険 衛 生 費 (保険医療費, 理容衛生費)

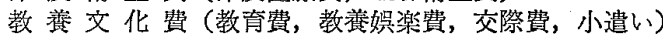

その他の雑費（交通・通信費たばこ，仕送り金，負担金，損害保険料，ての他）

○小遣いは，用途が複雑であるため，本調查では雑費の1品目として取り扱い，教養文化費に算入した。 
今回の家計調查では, 総理府家計調査統計の品目分類 に従い，集計段階ではこれをさらに簡略化して用いた。 （表-4.1，図-4.1）

まず収入額をみると，〈公営〉は実収入 6 万円で全国 勤労者世带（以下〈全国〉といら）とほぼ同水準にあり， 〈公団公社〉，〈分譲〉は各々 7.9 万円， 10.2 万円と 7 大 都市勤労者世带（以下〈7大都市〉といら）の6.9万円 を大きく上廻っている。収入構成に沶ける特徽は, 調查 世帯のいずれもが実収入以外の収入で〈全国〉より5千 円〜 7 千円少ないこと，実収入では世帯主の勤め先収入 の比率が〈全国〉より大きく，妻およびその他の世带員 の勤め先収入の比率が小さいこと，などである。前者は 勤め先収入への依存度が高い典型的なサラリーマン世带 が多いことの反映であり（サラリー以外に余り収入がな いこと)，後者は若い世帯がほとんどで共働き世帯も少 ないといら「団地」特有の性格をあらわすもの，とうけと れる。な拉〈公営〉の内職収入の比率が高いことは,千里 ニュータウンの郊外立地，およびその内部での保育所難 が主婦の職場進出の障害となり，ひいては内職に対する 傾斜を深めさせていることのあらわれとも考えられる。

一方消費支出額では，〈公営〉が 5 万円で〈全国〉にほ ぼ等しいが，〈7大都市〉の 5.7 万円に遠く及ばない。 〈公団公社〉の 6.5 万円，〈分譲〉の 8.6 万円はこれらを いずれも大きく上迴っている。

なお，これらの数字はいずれも各住宅階層の平均值で あるが，今これを各住宅階層の収人別に全国の人口 5 万 人以上の都市勤労者世帯 (以下〈5 万人以上都市〉とい 5）の同じ収入をもつ階層を比較すると、ニュータウン 居住世带は各住宅階層とも〈5万人以上都市〉よりも多 くの支出をしていることがわかる。しかし，この出費は， 〈公営〉〈公団公社〉にあっては，主として家賃による影 響のためであり，その他の食料費や雑費法同収入であれ ばそれほどの差はみられず，場合によってはむしろ低下 する例もみられる。この様な家賃による家計の圧迫は， 〈 7 大都市〉の 7,800 円にくらべて〈公営〉 2,500 円,〈公団 公社〉 5,000 円という貯金の低さにもあらわれている。

\section{5. 千里ニュータウン内外の購買施設選択傾向}

\section{1 千里ニュータウン計画における購買施設構成}

千里計画では，当初ニュータウン開発が単なるベッド タウン建設であることから脱したコミュニティーヴくり でめるために，近隣施設や各種公共施設が重要な役割を 果すものと考えられていた。そのため各種の施設は近隣 住区理論の下に，分区，住区，地区，全地区という空間 構成に応じて，各々のサービス圈からその内容と規模が 設定された。

購買施設については，従来の郊外住宅都市のごとく食 料品以外注とんど母都市に依存する様なことは止め， ニュータウン内で一応の消費生活を満足させるべく，
1,000 1,500 戸からなる 1 近隣分区に 1 近隣センター, （従って 2 分区よりなる 1 近隣住区には 2 近隣センター） $3 \sim 5$ 住区よりなる 1 地区に 1 地区センター, そして全 地区に 1 中央地区センター，といら段階的な構成が想定 された。

近隣センターは生鮮食料品を主体とするマーケット， 散髪, 美容, 哭茶, 軽食などのサービス店舗, それに日 用必需品の独立店舗などから構成され，公共施設,バス・ ストップなどとも有機的に結合されて近隣生活の中心と なる。地区センターは，千里ニュータウン外への高速鉄 道とニュータウン内のバス網との連絡点に位置し，近隣 センターにみられない高級衣料品, 教養, 文化, 娛楽関 倸の都心性商品が専門后におかれる。さらに中央地区セ ンターー泊貨店なども予定され，単に千里ニュータウン のみならず北大阪一帯のセンターとして，大阪の副都心 的性格が想定されている。

この様に千里計画では，従来の郊外住宅地にはみられ ない都心的商業的な活気をニュータウンに与え，居住者 の都心への流失をくいとめようとする意欲的な試みがみ られた。しかしながらすでに 1 近隣分区1近隣センター の構想はくずれ，計画戸数の入居が完了した今日におい ても 1 近隣住区 (2 分区) に 2 近隣センターー成立せず, 例外的に高野台住区で近隣センターとこれの補充として のサブセンターがあるにすぎない。また㘰区センターの 専門店にも空店が多く, 都心的な雾井気が感じられない。

日用必需品から都心性商品まで, 居住者の消費生活の 要求に念えるべく計画された干里ニュータウンの購買施 設構成は，果してその意図に沿って利用されているとい い得るであるうか。本節では, ニュータウン居住世帯の 千里内外の購買施設選択傾向を通して, 千里内購買施設 特に南地区センターの現在の性格を明らかにしょうとし た（なお，調查当時は北地区センターは未だ開店してい ない)。

\section{2 購買施設の概況}

本研究で調查を行なった千里ニュータウン内の住区は 任竹台, 高野台, 津雲台, 古江台, 藤白台, 青山台の 6 カ所で要るが，これらの住区を対象とする購買施設は， 南地区センターの購買施設 (以下〈地区〉といら), 各住 区近隣センターの購買施設（以下〈近隣〉といら），お上 び高野台住区のサブセンターの購買施設（以下〈サブ〉 といら)の 3 種類である。

阪急新千里山駅に接する〈地区〉には千里ニュータウ ンの南半分の住区を対象とする購買施設があるが，そこ には日常の食料品をあつからスーパーマーケットのほか に, 食堂喫茶, 女るいは時訫, めが祇, 宝不, 靴, 運動 具, レコードなどをあつから専門店があり，ほとんどの ものが購入出来る店舗計画になっている。また郵便局， 市役所出張所，銀行など各種サービス施設が同じセンタ 
一内にあり，駅に接していること，駐車場のあることな どの条件をあわせて，購買施設としては非常に有利な立 地条件のもとにある。

〈近隣〉の購買施設にしても, 食料品はもとより㲈物, 薬品, 電気器具までもの店舗をもち，かなりの品物につ いても〈近隣〉で購入出来る状況にある。食料品はマー ケットとしてひとまとめになっているが，マーケットの 経営方式は小売店が合同して開いている市場形式のもの やスーパーマーケットがー手にひきうけているものな ど住区によって違っており，それらの差異は客を引きつ ける面にかなりの影響をおよぼしている。しかし若下の 例をのぞいて，〈近隣〉の店舗構成は 1 業種 1 店舗の方 式がとられている。

〈サブ〉の購買施設はスーパーマーケットと酒類, 薬 品類，食堂などの独立店舗からなっているが，当初から 副次的購買施設として商圈も狭く計画されている。

\section{3 千里ニュータウン内外の消費支出品目構成}

まず調査総世帯の消費支出品目別に購買施設分布をみ ると，食料費では千里内が圧倒的に大きいのに比較し て，被服費がこれとは逆に千里外の大きいことが目立 つ。雑費は地点不明の項目の大部分を小遣いが占めると ころから千里外とみなしてもよいので，これを千里外に 入れると千里内が非常に少なくなる。以上から日常生活 に最も関連の深い食料品は千里内の購買施設でほぼまか なわれているといえるが，それ以外の被服，教養文化関
係の支出の大半は,千里外の梅田や心斎橋の都心商占街， の吹田, 淡路, 十三などの沿線商店街に流失しているこ および阪急沿線とがわかる（表一5.1，図-5.1）。

これは各購買施設に扝ける消費支出品目構成からみて も明らかである。千里内の〈サブ〉〈近隣〉〈地区〉,それに 自然に発生して定着しつつ亦る〈露店〉の各々に打るる食 料費の比率は，〈サブ〉75\%，〈近隣〉73\%，〈地区〉62\% となり，〈地区〉が若干低いだけでそれはどの差をみせ ない。しかもこの〈地区〉とその他の 10\% 強の差は, 主として款類，それも居住世带が〈近隣〉の米屋に登録 を余儀なくされている米麦類によるものであり，他の食 料品はほとんぞその差がみられない。〈露店〉は〈近隣〉 の生鮮食料品に対する不満の反映として定着しているも のだけに，生鮮食料品だけで $66 \% ，$ 食料品全体として $80 \%$ に達する。住居，被服，雑費関係でも，〈地区〉は

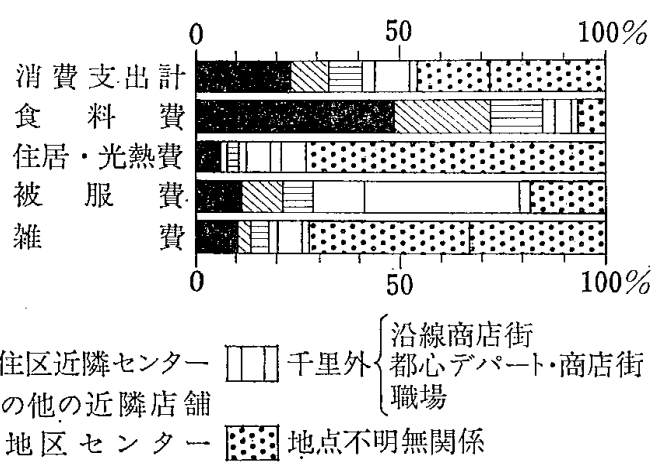

図-5.1

表一5.1 調查総世帯平均の消費支出品目別購買施設分布括よび購買施設別消費支出目構成

(単位：円)

\begin{tabular}{|c|c|c|c|c|c|c|c|c|c|c|c|c|c|c|}
\hline \multirow[b]{2}{*}{ 品 } & \multirow[b]{2}{*}{ 合 計 } & \multicolumn{3}{|c|}{$千$} & \multicolumn{2}{|c|}{ 地 } & \multicolumn{2}{|l|}{ 区 } & \multicolumn{2}{|c|}{ 地 } & \multicolumn{2}{|l|}{ 外 } & \multirow{2}{*}{$\begin{array}{l}\text { 地 点 } \\
\text { 明 }\end{array}$} & \multirow{2}{*}{$\begin{array}{l}\text { 地 点 } \\
\text { 無関係 }\end{array}$} \\
\hline & & 小 計 & $\begin{array}{l}\text { 筫住区 } \\
\text { 隣七 } \\
\text { シター }\end{array}$ & $\begin{array}{l}\text { 自住区 } \\
\text { サブセ } \\
\text { ンター }\end{array}$ & $\begin{array}{l}\text { 他住区 } \\
\text { 近䧛セ } \\
\text { ンター }\end{array}$ & $\begin{array}{l}\text { 千量南 } \\
\text { 地区セ } \\
\text { y多一 }\end{array}$ & $\begin{array}{l}\text { 配達御 } \\
\text { 用聞き }\end{array}$ & $\begin{array}{l}\text { 䔟動斯 } \\
\text { 売蕗店 }\end{array}$ & 小 計 & $\begin{array}{l}\text { 沿楾 } \\
\text { 商店街 }\end{array}$ & $\begin{array}{l}\text { 都心デ } \\
\text { 怘! } \\
\text { 商店街 } \\
\end{array}$ & 職 場 & & \\
\hline 消費支出訫 & 61,915 & 24,977 & 13,955 & 998 & 2,528 & 4,257 & 2,079 & 1,149 & 8,785 & 2,154 & 5,461 & 1,170 & 11,425 & 16,738 \\
\hline 食＼cjkstart料 & 20,870 & 17,836 & 10,235 & 745 & 1,660 & 2,630 & 1,628 & 918 & 1,911 & 687 & 939 & 283 & 1,122 & - \\
\hline 款 類 & 3,143 & 2,916 & 2,399 & 72 & 177 & 164 & 72 & 34 & 132 & 75 & 41 & 15 & 95 & $\ldots$ \\
\hline 生䚙食料費 & 9,841 & 9,183 & 4,710 & 346 & 945 & 1,461 & 967 & 753 & 592 & 325 & 254 & 11 & 66 & - \\
\hline その他食料費 & 7,886 & 5,736 & 3,107 & 327 & 538 & 1,005 & 588 & 131 & 1,187 & 287 & 644 & 257 & 961 & - \\
\hline 住居 - 光熱費 & 14,656 & 1,750 & 915 & 73 & 202 & 481 & 58 & 21 & 1,489 & 329 & 866 & 295 & 1,032 & 10,319 \\
\hline 被 服 費 & 6,404 & 1,825 & 705 & 47 & 180 & 461 & 265 & 168 & 3,570 & 863 & 2,501 & 206 & 1,009 & - \\
\hline & 20,002 & 3,585 & 2,111 & 133 & 485 & 685 & 129 & 42 & 1,815 & 274 & 1,155 & 386 & 8,188 & 6,411 \\
\hline 保険・衛生費 & 3,215 & 1,842 & 1,210 & 113 & 286 & 130 & 77 & 26 & 316 & 125 & 154 & 38 & 1,057 & - \\
\hline 教養·文化費 & 11,155 & 1,496 & 748 & 20 & 184 & 479 & 48 & 17 & 1,289 & 141 & 962 & 186 & 7,132 & 1,237 \\
\hline との他の雑費 & 5,632 & 249 & 154 & 1 & 15 & 75 & 5 & 0 & 209 & 9 & 39 & 163 & 0 & 5,174 \\
\hline 消費支出計 （\%) & & $\begin{array}{r}(100.0) \\
40.2\end{array}$ & $\begin{array}{c}(100.0) \\
22.6\end{array}$ & $\begin{array}{r}(100.0) \\
1.6\end{array}$ & $\begin{array}{c}(100.0) \\
4.0\end{array}$ & $\begin{array}{c}(100.0) \\
6.9\end{array}$ & $\begin{array}{c}(100.0) \\
3.2\end{array}$ & $\begin{array}{r}(100.0) \\
1.8\end{array}$ & $\begin{array}{c}(100.0) \\
14.2\end{array}$ & $\begin{array}{c}(100.0) \\
3.5\end{array}$ & $\begin{array}{r}(100.0) \\
8.8\end{array}$ & $\begin{array}{c}(100.0) \\
1.9\end{array}$ & $\begin{array}{c}(100.0) \\
18.5\end{array}$ & $\begin{array}{r}(100.0) \\
27.0\end{array}$ \\
\hline 食 料 費 & $(33.7)$ & $(71.5)$ & $\begin{array}{l}(73.3) \\
490\end{array}$ & $(74.6)$ & $(65.7)$ & $(61.8)$ & $\begin{array}{r}(78.5) \\
7.8\end{array}$ & $(79.9)$ & $\begin{array}{r}(21.7) \\
9.2\end{array}$ & $(31.8)$ & $(17.2)$ & $(24.2)$ & $(9.8)$ & - \\
\hline 㩰 & & $(11.7)$ & $(17.2)$ & $(7.2)$ & $(7.0)$ & $(3.9)$ & $\left(\begin{array}{l}7.8 \\
0.5\end{array}\right.$ & $\left(\begin{array}{c}4.4 \\
3.0\end{array}\right)$ & $\left(\begin{array}{l}9.5 \\
1.5\end{array}\right)$ & $\left(\begin{array}{l}3.0 \\
3.5\end{array}\right)$ & $(7.5)$ & $(1.3)$ & $(0.8)$ & - \\
\hline & & $\begin{array}{c}92.8 \\
(36.8)\end{array}$ & $\begin{array}{l}76.3 \\
(33.8)\end{array}$ & $\begin{array}{r}2.3 \\
(34.7)\end{array}$ & $\begin{array}{c}5.6 \\
(37.4)\end{array}$ & $\begin{array}{c}5.2 \\
(34.3)\end{array}$ & $\begin{array}{c}2.3 \\
(46.6)\end{array}$ & $\begin{array}{l}1.1 \\
(65.5)\end{array}$ & $\left(\begin{array}{l}4.2 \\
(6.7)\end{array}\right.$ & $\begin{array}{c}2.4 \\
(15.1)\end{array}$ & $\left(\begin{array}{l}1.4 \\
4.7\end{array}\right)$ & $\left(\begin{array}{l}0.5 \\
0.9)\end{array}\right.$ & $\left(\begin{array}{l}3.0 \\
0.6)\end{array}\right.$ & 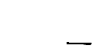 \\
\hline 生 鮮 食料 費 & 100.0 & 93.3 & 47.9 & 3.5 & 9.6 & 14.8 & 9.8 & 7.7 & 6.0 & 3.3 & 2.6 & 1.1 & 6.7 & - \\
\hline その他食料費 & $\begin{array}{l}2.7) \\
0\end{array}$ & $\begin{array}{l}(23.0) \\
72.6\end{array}$ & $\begin{array}{l}(20.1) \\
39.4\end{array}$ & $\begin{array}{c}(32.7) \\
4.1\end{array}$ & $\begin{array}{c}(21.3) \\
6.8\end{array}$ & $\begin{array}{l}(23.7) \\
12.7\end{array}$ & (28.3) & $(11.4)$ & $(13.5)$ & $\begin{array}{c}(13.3) \\
3.7\end{array}$ & $\begin{array}{r}(11.4) \\
8.2\end{array}$ & $\begin{array}{c}(31.9) \\
3.3\end{array}$ & $\left(\begin{array}{c}8.4) \\
12.3\end{array}\right.$ & - \\
\hline & & $(7.1)$ & $(6.6)$ & $(7.3)$ & $\left(\begin{array}{l}0.0 \\
8.0\end{array}\right)$ & $(11.3)$ & $(2.8)$ & $\left(\begin{array}{l}1.0 \\
(1.8)\end{array}\right)$ & $(16.9)$ & $(15.2)$ & (15.9) & $(25.2)$ & $(9.0)$ & $(61.6)$ \\
\hline 柱 居 - 光 熱 頨 & & 11.9 & 6.2 & 0.5 & 1.4 & 3.3 & 0.4 & 0.1 & 10.2 & 2.2 & 5.9 & 2.0 & 7.0 & 70.4 \\
\hline 被服 & (10.3) & $\left(\begin{array}{l}7.3 \\
28.5\end{array}\right)$ & $(5.1)$ & $(4.7)$ & $(7.1)$ & $\left(\begin{array}{r}(10.8) \\
7.2\end{array}\right)$ & $(12.8)$ & $(14.6)$ & $\begin{array}{l}(40.6) \\
55.8\end{array}$ & $\begin{array}{l}(40.0) \\
13.5\end{array}$ & $\begin{array}{c}(45.8) \\
39.1\end{array}$ & $\begin{array}{c}(17.6) \\
3.2\end{array}$ & $\begin{array}{l}(8.8) \\
15.8\end{array}$ & - \\
\hline & $(32.3)$ & $(14.4)$ & $(15.1)$ & $(13.3)$ & $(19.2)$ & $(16.1)$ & $(6.2)$ & $(3.7)$ & $(20.7)$ & $(12.7)$ & $(21.1)$ & $(33.0)$ & $(71.5)$ & $(38.3)$ \\
\hline & & $18.0^{\circ}$ & 10.6 & 0.7 & 2.4 & 3.4 & 0.6 & 0.2 & 9.1 & 1.4 & 5.8 & 2.0 & 41.0 & $32.0^{\circ}$ \\
\hline 保険 - 衛生費 & $\begin{array}{l}(5.2) \\
100.0\end{array}$ & $\begin{array}{c}(7.4) \\
57.3\end{array}$ & $\begin{array}{c}(8.7) \\
37.6\end{array}$ & $\begin{array}{c}(11.3) \\
3.5\end{array}$ & $\begin{array}{c}(11.3) \\
8.9\end{array}$ & $\left(\begin{array}{c}3.1 \\
4.0\end{array}\right)$ & $\begin{array}{c}(3.7) \\
2.4\end{array}$ & $\left.\begin{array}{c}(2.3) \\
0.8\end{array}\right)$ & $\begin{array}{c}(3.6) \\
9.8\end{array}$ & $\begin{array}{c}(5.8) \\
3.9\end{array}$ & $\begin{array}{c}(2.8) \\
4.8\end{array}$ & $\begin{array}{c}(3.3) \\
1.2\end{array}$ & $\begin{array}{c}(9.2) \\
32.9\end{array}$ & - \\
\hline 教養 - 文化費 & $(13.1)$ & $(6.0)$ & $\left(\begin{array}{l}5.3) \\
6.7\end{array}\right.$ & $\left(\begin{array}{l}2.0) \\
0.2\end{array}\right.$ & $\begin{array}{l}(7.3) \\
1.6\end{array}$ & $\left(\begin{array}{rl}11.3 \\
4.3\end{array}\right.$ & $\left(\begin{array}{r}2.3 \\
0.4\end{array}\right)$ & $\left(\begin{array}{c}1.5 \\
0.2\end{array}\right)$ & $\begin{array}{l}(14.4) \\
11.6\end{array}$ & $\begin{array}{l}(6.5) \\
1.3\end{array}$ & $\begin{array}{c}(17.6) \\
8.6\end{array}$ & $\begin{array}{c}(13.8) \\
1.7\end{array}$ & $\begin{array}{c}(62.3) \\
63.9\end{array}$ & $\begin{array}{l}(7.4) \\
11.1\end{array}$ \\
\hline その他の雑費 & $\begin{array}{l}(13.9) \\
100.0\end{array}$ & $\left(\begin{array}{l}(1.0) \\
4.4\end{array}\right.$ & $\begin{array}{l}(1.2) \\
2.7\end{array}$ & $\left(\begin{array}{l}1.0) \\
0\end{array}\right.$ & $\begin{array}{c}(0.6) \\
0.3\end{array}$ & $\begin{array}{c}(17.6) \\
1.3\end{array}$ & $\left(\begin{array}{c}0.2 \\
0.1\end{array}\right)$ & $\left(\begin{array}{l}0 \\
0\end{array}\right)$ & $\begin{array}{c}(2.7) \\
3.7\end{array}$ & $\begin{array}{c}(4.2) \\
0.2\end{array}$ & $\begin{array}{c}(0.7) \\
0.7\end{array}$ & $\begin{array}{r}(16.1) \\
2.9\end{array}$ & $\left(\begin{array}{l}0 \\
0\end{array}\right)$ & $\begin{array}{c}(30.9) \\
91.9\end{array}$ \\
\hline
\end{tabular}

註） \%の關で（）内の数字は，㹕買施設別消費支出品目の比率（（）のない数字は消費支出品目別購買施設の此率。 
若干他を上迴るが，これとても〈地区〉の都心的性格を 裹付けるには程遠い。これらの点加ら教えて〈地区〉は 食料品中心の大型近隣センターに他ならないといえる (図一5.1')。

\section{4 居住世帯による購買施設利用形態の変化}

千里ニュータウン居住抴带の消費支出構成が，最寄 品・日用必需品は千里内で, 買廻り品・専門品は千里外 と分れており, 従って地区センターは大型近隣センター 化していることはすでに述べた。この全体的な傾向を居 住世带の性格一一住宅階層, 収入, 家族人数, 主婦の労 働形態一—と相関させ，どの様な対応関係にあるかを次 に明らかにする。(表一-5，2，図一5．2）

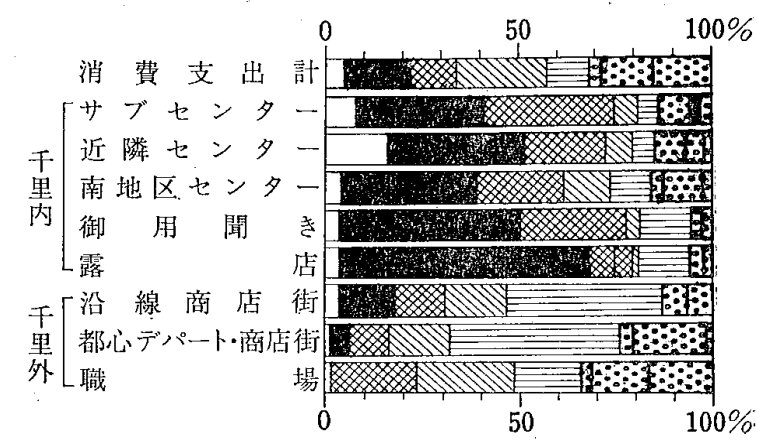

$\square$ 㪍 類 住居光熱費 的解食料費被 服 費 その他の食料費 费

図一5.1

収入階層注大体住宅階層乞対応し ているので，住宅階層による違いを みると，〈公営〉が千里内 2.2 万円・ $44 \%$ ，千里外 1.2 万円 $24 \%$ （雑費 の地点不明の項目は主として千里外

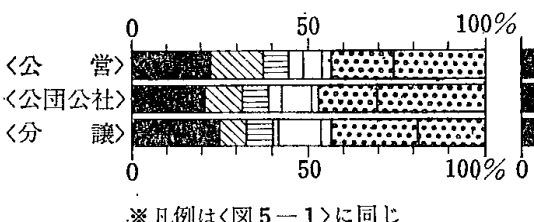

※凡例はく図 5-1〉に同じ

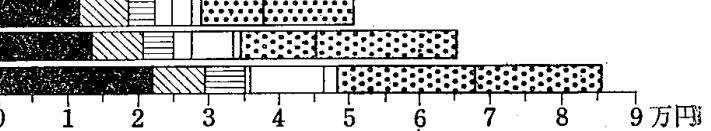

図一 5.2

表一5.2 住宅階層別, 消費支出品目別, 購買施設分布 (単位：円）

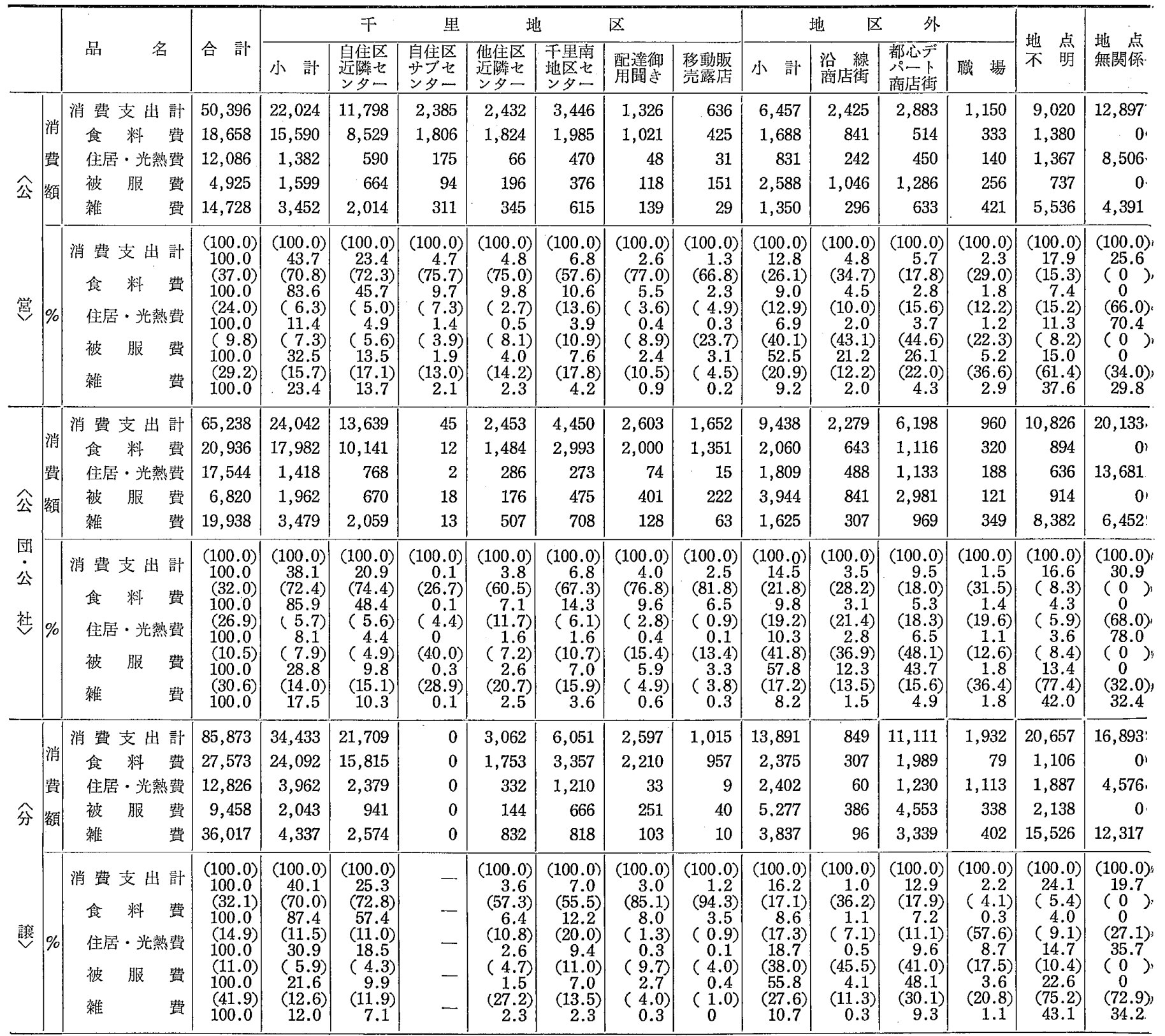

註）公営住宅 93 世带, 公団公社住宅 103 世带, 分謡住宅 31 世带。 


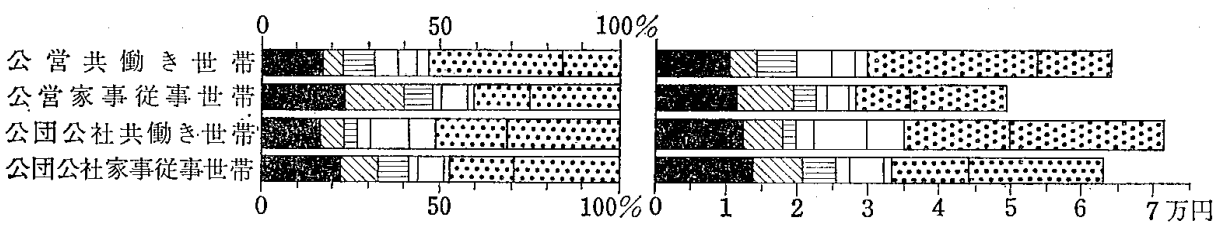

※凡例は〈図 $5-1$ ○に同じ

図一5.3
内 3.4 万円 $40 \%$, 千里外 2.9 万 円・34\%となって，収入が増加す る程千里内外共に支出額はますが， 千里内支出率法下し千里外がふえ る傾向にある。これは高収入であれ。 ばある程買廻り品・専門品の支出が

の小遣いなので千里外に算入した)，〈公団公社〉が千里＼cjkstart増えるからと思われる。なお千里外での購買施設につい 内 2.5 万円・38\%,千里外 1.8 万円・27\%，〈分譲〉は千里 ては,住宅階層によって興味深い動向がみられる。例えば

表一5.3 住宅階層別, 主婦学働形態別, 消費支出品目別, 購買施設分布

\begin{tabular}{|c|c|c|c|c|c|c|c|c|c|c|c|c|c|c|c|}
\hline & & \multirow[b]{2}{*}{ 合 計 } & \multicolumn{3}{|c|}{$千$} & \multicolumn{2}{|c|}{ 地 } & \multicolumn{2}{|c|}{ 区 } & \multicolumn{2}{|c|}{ 地 } & \multicolumn{2}{|c|}{ 区 外 } & \multirow{2}{*}{$\begin{array}{ll}\text { 地 } & \text { 点 } \\
\text { 不 } & \text { 明 }\end{array}$} & \multirow{2}{*}{$\begin{array}{l}\text { 地 点. } \\
\text { 無関係: }\end{array}$} \\
\hline & & & 小 計 & $\begin{array}{l}\text { 自住区 } \\
\text { 近僯せ } \\
\text { ンター }\end{array}$ & $\begin{array}{l}\text { 自住区 } \\
\text { ザブセ } \\
\text { ンター }\end{array}$ & $\begin{array}{l}\text { 他住区 } \\
\text { 近隣七 } \\
\text { ンター }\end{array}$ & $\begin{array}{l}\text { T里南 } \\
\text { 地区せ } \\
\text { ンタ二 }\end{array}$ & $\begin{array}{l}\text { 配達御 } \\
\text { 角聞さ }\end{array}$ & $\begin{array}{l}\text { 多動股 } \\
\text { 売露店 }\end{array}$ & 小 計 & 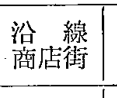 & $\begin{array}{l}\text { 都心デ } \\
\text { パ-下 } \\
\text { 商后街 }\end{array}$ & 職 場 & & \\
\hline & 消費支出計 & 63,236 & 20,127 & 10,674 & 1,254 & 1,860 & 5,465 & 620 & 254 & 9,677 & 4,905 & 3,050 & 1,722 & 23,817 & 9,615 \\
\hline 消 & 食 料 虫 & 20,045 & 13,797 & 7,642 & 1,153 & 1,275 & 3,114 & 385 & 228 & 4,118 & 2,871 & 501 & 746 & 2,130 & \\
\hline 湄 & 住居 - 光蓺葿 & 18,542 & 2,277 & 878 & 0 & 41 & 1,176 & 182 & 0 & 909 & 169 & 648 & 92 & 6,854 & 8,501 \\
\hline 共額 & 被 服 費 & 5,595 & 1,228 & 394 & 0 & 268 & 493 & 53 & 20 & 3,639 & 1,481 & 1,461 & 697 & 729 & \\
\hline 働 & 熦茜 & 19,054 & 2,825 & 1,761 & 102 & 275 & 682 & 0 & 6 & 1,010 & 384 & 440 & 187 & 14,104 & 1,114 \\
\hline 公带 $\%$ & 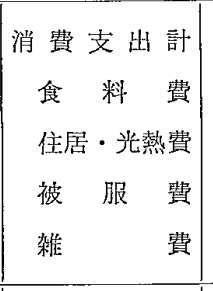 & $\begin{array}{l}(100.0) \\
100.0 \\
(31.6) \\
100.0 \\
(29.3) \\
100.0 \\
(8.8) \\
100.0 \\
(30.0) \\
100.0\end{array}$ & $\begin{array}{c}(100.0) \\
31.8 \\
(68.5) \\
68.8 \\
(11.3) \\
12.3 \\
(6.1) \\
22.0 \\
(14.0) \\
14.8\end{array}$ & $\begin{array}{c}(100.0) \\
16.9 \\
(71.5) \\
38.1 \\
(8.2) \\
4.7 \\
(3.7) \\
7.0 \\
(16.5) \\
9.2\end{array}$ & $\begin{array}{c}(100.0) \\
2.0 \\
(92.0) \\
5.8 \\
0 \\
0 \\
(8.1) \\
0.5\end{array}$ & $\begin{array}{r}(100.0) \\
2.9 \\
(68.6) \\
6.4 \\
(2.2) \\
0.2 \\
(14.4) \\
4.8 \\
(14.8) \\
1.4\end{array}$ & $\begin{array}{c}(100.0) \\
8.6 \\
(57.0) \\
15.5 \\
(21.5) \\
6.3 \\
(9.3) \\
8.8 \\
(12.4) \\
3.6\end{array}$ & $\begin{array}{c}(100.0) \\
1.0 \\
(62.2) \\
1.9 \\
(29.4) \\
1.0 \\
\left(\begin{array}{c}8.5 \\
1.0 \\
(0 \\
0\end{array}\right)\end{array}$ & $\begin{array}{c}(100.0) \\
0.4 \\
(89.7) \\
1.1 \\
(0 \\
0 \\
(7.9) \\
0.4 \\
\left(\begin{array}{l}2.4 \\
0 \\
0\end{array}\right)\end{array}$ & $\begin{array}{c}(100.0) \\
15.3 \\
(42.7) \\
20.5 \\
(9.4) \\
4.9 \\
(37.6) \\
65.0 \\
(10.3) \\
5.3\end{array}$ & $\begin{array}{c}(100.0) \\
7.8 \\
(58.5) \\
14.3 \\
(3.4) \\
0.9 \\
(30.2) \\
26.5 \\
(7.8) \\
2.0\end{array}$ & $\begin{array}{c}(100.0) \\
4.8 \\
(16.4) \\
2.4 \\
(21.2) \\
3.5 \\
(48.0) \\
26.1 \\
(14.4) \\
2.3\end{array}$ & $\begin{array}{c}(100.0) \\
2.7 \\
(43.3) \\
3.7 \\
(5.3) \\
0.5 \\
(40.4) \\
12.4 \\
(10.9) \\
0.9\end{array}$ & $\begin{array}{c}(100.0) \\
37.6 \\
(8.9) \\
10.6 \\
(28.8) \\
37.0 \\
(3.1) \\
13.0 \\
(59.2) \\
74.0\end{array}$ & $\begin{array}{c}(100.0) \\
15.2 \\
\left(\begin{array}{l}0 \\
0\end{array}\right) \\
(88.4) \\
45.8 \\
\left(\begin{array}{c}0 \\
0 \\
(11.6 \\
5.8\end{array}\right)\end{array}$ \\
\hline & 消費支出計 & 48,333 & 2,466 & 11,328 & 2,971 & 2,807 & 3,171 & 1,333 & 852 & 5,681 & 1,641 & 3,169 & 871 & 7,778 & 12,410 \\
\hline & 食 料 費 & 18,208 & 15,853 & 8,270 & 2,103 & 2,237 & 1,566 & 1,061 & 610 & 1,244 & 468 & 540 & 236 & 1,110 & 0 \\
\hline 家費 & 住居 - 光熱費 & 11,421 & 1,265 & 354 & 254 & 62 & 507 & 32 & 56 & 872 & 231 & 410 & 231 & 745 & 8,540 \\
\hline 営我管 & 被 服 費 & 4,577 & 1,630 & 694 & 144 & 159 & 400 & 72 & 160 & 2,231 & 736 & 1,489 & 6 & 716 & 0 \\
\hline 事: & 雑 費 & 14,127 & 3,718 & 2,009 & 469 & 349 & 698 & 168 & 26 & 1,334 & 205 & 730 & 399 & 5,207 & 3,870 \\
\hline 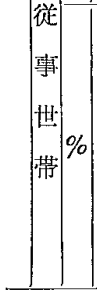 & $\begin{array}{cr}\text { 消費 支出 } \\
\text { 食 } \\
\text { 評 }\end{array}$ & $\begin{array}{l}(100.0) \\
100.0 \\
(37.6) \\
100.0 \\
(23.7) \\
100.0 \\
(9.4) \\
100.0 \\
(29.5) \\
100.0\end{array}$ & $\begin{array}{c}(100.0) \\
46.5 \\
(70.5) \\
87.1 \\
(5.6) \\
11.1 \\
(7.2) \\
35.6 \\
(16.5) \\
26.3\end{array}$ & $\begin{array}{c}(100.0) \\
23.4 \\
(73.0) \\
45.4 \\
(3.1) \\
3.8 \\
(6.1) \\
15.2 \\
(17.7) \\
14.2\end{array}$ & $\begin{array}{c}(100.0) \\
6.2 \\
(71.0) \\
11.5 \\
(8.5) \\
2.2 \\
(4.9) \\
3.0 \\
(15.7) \\
3.3\end{array}$ & $\begin{array}{c}(100.0) \\
5.8 \\
(79.5) \\
12.3 \\
(2.2) \\
0.5 \\
(5.7) \\
3.4 \\
(12.5) \\
2.5\end{array}$ & $\begin{array}{c}(100.0) \\
6.6 \\
(49.2) \\
8.5 \\
(16.0) \\
4.0 \\
(12.6) \\
8.7 \\
(22.0) \\
4.9\end{array}$ & $\begin{array}{c}(100.0) \\
2.8 \\
(79.3) \\
5.8 \\
(2.4) \\
0.3 \\
(5.4) \\
1.6 \\
(12.6) \\
1.2\end{array}$ & $\begin{array}{c}(100.0) \\
1.8 \\
(71.6) \\
3.4 \\
(6.6) \\
0.4 \\
(18.8) \\
3.5 \\
(3.0) \\
0.2\end{array}$ & $\begin{array}{c}(100.0) \\
11.8 \\
(21.9) \\
6.9 \\
(15.3) \\
7.6 \\
(39.3) \\
48.7 \\
(23.5) \\
9.4\end{array}$ & $\begin{array}{c}(100.0) \\
3.4 \\
(28.6) \\
2.6 \\
(14.1) \\
2.0 \\
(45.0) \\
16.0 \\
(12.5) \\
1.5\end{array}$ & $\begin{array}{c}(100.0) \\
6.6 \\
(17.1) \\
3.0 \\
(12.9) \\
3.6 \\
(47.0) \\
32.5 \\
(23.0) \\
5.8\end{array}$ & $\begin{array}{c}(100.0) \\
1.8 \\
(27.1) \\
1.3 \\
(26.4) \\
2.0 \\
(0.6) \\
0.1 \\
(45.7) \\
2.8\end{array}$ & $\begin{array}{c}(100.0) \\
16.1 \\
(14.3) \\
6.1 \\
(9.6) \\
6.5 \\
(9.2) \\
15.6 \\
(67.0) \\
36.8\end{array}$ & $\begin{array}{c}(100.0) \\
25.7 \\
(0) \\
0 \\
(68.8) \\
74.8 \\
(0) \\
0 \\
(31.1) \\
27.4\end{array}$ \\
\hline & 消費支出計 & 72,359 & 18,953 & 12,485 & 0 & 2,666 & 1,619 & 1,587 & 596 & 15,627 & 2,768 & 7,478 & 5,381 & 14,599 & 23,174 \\
\hline 消 & 食 料 嘪 & 21,904 & 13,240 & 8,577 & 0 & 1,967 & 982 & 1,258 & 456 & 518 & 1,388 & 3,189 & 1,940 & 2,141 & 0 \\
\hline 蛽 & 住居 - 光熱費 & 17,141 & 1,909 & 1,679 & 0 & 180 & 51 & 0 & 0 & 1,372 & 543 & 393 & 436 & 484 & 13,376 \\
\hline 共頙 & 被 服 費 & 6,128 & 1,018 & 266 & 0 & 65 & 234 & 329 & 124 & 4,703 & 564 & 3,059 & 1,080 & 407 & 0 \\
\hline 働 & 䕌 費 & 27,186 & 2,785 & 1,964 & 0 & 454 & 351 & 0 & 16 & 3,035 & 272 & 837 & 1,926 & 11,567 & 9,798 \\
\hline 帯 $\%$ & 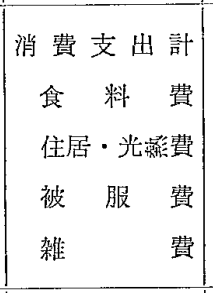 & $\begin{array}{c}(100.0) \\
100.0 \\
(30.1) \\
100.0 \\
(23.7) \\
100.0 \\
(8.5) \\
100.0 \\
(37.5) \\
100.0\end{array}$ & $\begin{array}{c}(100.0) \\
26.2 \\
(69.8) \\
60.5 \\
(10.0) \\
11.1 \\
(5.4) \\
16.6 \\
(14.7) \\
10.2\end{array}$ & $\begin{array}{c}(100.0) \\
17.2 \\
(68.7) \\
39.2 \\
(13.4) \\
9.8 \\
(2.1) \\
4.3 \\
(15.8) \\
7.2\end{array}$ & $\begin{array}{l}0 \\
0 \\
0 \\
0\end{array}$ & $\begin{array}{c}(100.0) \\
3.7 \\
(73.7) \\
9.0 \\
(6.8) \\
1.1 \\
(2.4) \\
1.0 \\
(17.0) \\
1.7\end{array}$ & $\begin{array}{r}(100.0) \\
2.2 \\
(60.6) \\
4.5 \\
(3.2) \\
0.3 \\
(14.5) \\
3.8 \\
(21.7) \\
1.3\end{array}$ & $\left.\begin{array}{c}(100.0) \\
2.2 \\
(79.2) \\
5.7 \\
(0 \\
0 \\
(20.8) \\
5.4 \\
(0 \\
0\end{array}\right)$ & $\begin{array}{c}(100.0) \\
0.8 \\
(76.6) \\
2.1 \\
(0) \\
0 \\
(20.8) \\
2.0 \\
(2.7) \\
0.5\end{array}$ & $\begin{array}{c}(100.0) \\
21.6 \\
(41.6) \\
29.7 \\
(8.8) \\
8.0 \\
(30.2) \\
76.6 \\
(19.4) \\
11.2\end{array}$ & $\begin{array}{c}(100.0) \\
3.8 \\
(50.1) \\
6.3 \\
(19.6) \\
3.2 \\
(20.4) \\
9.2 \\
(9.9) \\
1.0\end{array}$ & $\begin{array}{c}(100.0) \\
10.4 \\
(42.6) \\
14.6 \\
(5.3) \\
2.2 \\
(40.8) \\
49.9 \\
(11.2) \\
3.0\end{array}$ & $\begin{array}{c}(100.0) \\
7.4 \\
(36.1) \\
8.9 \\
(8.1) \\
2.6 \\
(20.1) \\
17.6 \\
(35.8) \\
7.1\end{array}$ & $\begin{array}{c}(100.0) \\
20.2 \\
(14.7) \\
9.7 \\
(3.3) \\
2.8 \\
(2.8) \\
6.6 \\
(79.3) \\
42.5\end{array}$ & 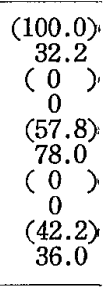 \\
\hline 公 & 消費支出計 & 62,697 & 25,518 & 13,625 & 60 & 2,394 & 5,055 & 2,614 & 1,770 & 110 & 1,785 & 5,663 & 664 & 10,514 & 18,550 \\
\hline & 食 㰾 費 & 20,467 & 18,205 & 10,008 & 16 & 1,397 & 3,357 & 1,972 & 1,455 & 1,454 & 436 & 831 & 187 & 808 & 0 \\
\hline & 住居 - 光蓺費 & 17,307 & 1,498 & 728 & 2 & 330 & 327 & 97 & 14 & 1,666 & 334 & 1,123 & 210 & 723 & 13,419 \\
\hline 社 南 & 被 服 費 & 7,073 & 2,076 & 696 & 24 & 183 & 547 & 381 & 244 & 3,919 & 821 & 3,035 & 63 & 1,077 & 0 \\
\hline & 雑責 & 17,849 & 3,738 & 2,192 & 17 & 484 & 825 & 164 & 55 & 1,073 & 195 & 675 & 204 & 7,906 & 5,131 \\
\hline 带 $\%$ & 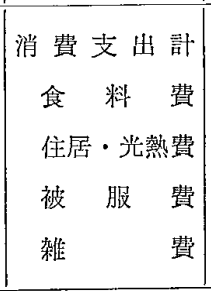 & $\begin{array}{l}(100.0) \\
100.0 \\
(32.7) \\
100.0 \\
(27.6) \\
100.0 \\
(11.3) \\
100.0 \\
(28.5) \\
100.0\end{array}$ & $\begin{array}{c}(100.0) \\
40.7 \\
(71.4) \\
89.0 \\
(5.9) \\
8.7 \\
(8.1) \\
29.4 \\
(14.6) \\
21.0\end{array}$ & $\begin{array}{c}(100.0) \\
21.8 \\
(73.4) \\
48.8 \\
(5.3) \\
4.2 \\
(5.1) \\
9.8 \\
(16.1) \\
12.3\end{array}$ & $\begin{array}{l}0 \\
0 \\
0\end{array}$ & $\begin{array}{r}(100.0) \\
3.8 \\
(58.3) \\
6.8 \\
(13.8) \\
1.9 \\
(7.6) \\
2.6 \\
(20.2) \\
2.7\end{array}$ & \begin{tabular}{|c}
$(100.0)$ \\
8.1 \\
$(66.5)$ \\
9.6 \\
$(6.5)$ \\
1.9 \\
$(10.8)$ \\
7.7 \\
$(16.3)$ \\
4.6
\end{tabular} & $\begin{array}{c}(100.0) \\
4.2 \\
(75.4) \\
16.4 \\
(3.7) \\
0.6 \\
(14.6) \\
5.4 \\
(6.3) \\
0.9\end{array}$ & $\begin{array}{c}(100.0) \\
2.8 \\
(82.2) \\
7.1 \\
(0.8) \\
0.1 \\
(13.8) \\
3.4 \\
(3.1) \\
0.3\end{array}$ & $\begin{array}{c}(100.0) \\
12.8 \\
(17.9) \\
7.1 \\
(20.5) \\
9.6 \\
(48.3) \\
55.3 \\
(13.3) \\
6.0\end{array}$ & $\begin{array}{c}(100.0) \\
2.8 \\
(24.4) \\
2.1 \\
(18.7) \\
1.9 \\
(46.0) \\
11.5 \\
(10.9) \\
1.1\end{array}$ & $\begin{array}{c}(100.0) \\
9.0 \\
(14.7) \\
4.0 \\
(19.8) \\
6.5 \\
(53.5) \\
43.0 \\
(11.9) \\
3.8\end{array}$ & $\begin{array}{r}(100.0) \\
1.0 \\
(28.2) \\
0.9 \\
(31.6) \\
1.2 \\
(9.5) \\
0.9 \\
(30.7) \\
1.1\end{array}$ & $\begin{array}{c}(100.0) \\
16.8 \\
(7.7) \\
3.9 \\
(6.9) \\
4.2 \\
(10.2) \\
15.3 \\
(75.2) \\
44.2\end{array}$ & $\begin{array}{c}(100.0) \\
29.6 \\
(0) \\
0 \\
(72.4) \\
77.9 \\
(0) \\
0 \\
(27.6) \\
28.8\end{array}$ \\
\hline
\end{tabular}

註）公営住宅共働き世带 11 ，家事彷事世帯 52 ，公団公社共働き世带 17 ，家事從事世带 78 
流失率の最も高い被服費でこの動向をみると，都心商店 街・デパートと沿線商店街の比は,〈公営〉で $26 \%: 21 \%$, 〈公団公社〉 $44 \%: 12 \%$ ，〈分譲〉 $48 \%: 4 \%$ となって， 収入が高くなる程都心の購買施設への傾斜が強くなるこ とが分る。

家族人数による变化は，ニュータウン居住世帯のほと んぞが若い小家族中心であるため，それ程はっきりとは あらわれない。ただ共働きの影響によるものか，若い 2 人世帯の千里外支出率は高く, 〈公営〉 1.4 万円・ $31 \%$, 〈公団公社〉 2.8 万円・ $42 \%$ といった特徽がみられる程 度である。

主婦の労働形態による相異は, ことに共働き世带と家 事徒事世帯とで大きい（内職世帯は独立させて分類した が顕著な性格を示さないのでここでは取上げない）千里
外支出率は共働き世带が〈公営〉 2.4 万円・ $36 \%$ ，〈公団 公社〉 2.7 万円 $37 \%$ に対して, 家事従事世帯はく公 営〉 1.1 万円 $\cdot 21 \%$ ，〈公団公社〉 1.6 万円 $25 \%$ にと ぞまっている。共働き世帶では，被服費のうち，〈公営〉 3,600 円・ $65 \%$ ，〈公団公社〉 4,200 円・77\%，が千里外 であり，近隣性の強い食料費ですら〈公営〉 4,100 円・ $21 \%$ ，〈公団公社〉 6,500 円・30\% が千里外に流失して いる。この様に共働き世带は, 家事世帯にくらべて同じ 住宅階層内に扔いても比較的高収入階層に属し，しかも 買物の主要な担い手である主婦が都心や沿線で働いてい るところから，通勤の帰途の都心商占街・デパートや沿 線商店街での買物が一般化し, 従来の家庭の主婦とは, 異なった購買慣習が成立しているからと思われる（表一 5.3 , 図-5.3)。

(次号に続く) 